of adequate armaments and compulsory military training; secondly, full employment as a condition of individual self-respect and independence, and as a guarantee that the maximum effort is being harnessed to the national objectives; thirdly, the provision of homes for all of an adequate standard; fourthly, the establishment of an educational system which will enable any child to develop his capacities and character to the full; and fifthly, social security guaranteed by adequate minimum wages and a system of social insurance on the lines proposed by Sir William Beveridge.

\section{Transport Problems in Reconstruction}

SuPPLEMENTING two earlier broadsheets, Nos. 202 and 207, on "Retail Distribution and Town Planning" and on "Space for Leisure", respectively, Political and Economic Planning has now issued a further broadsheet in its attempt to analyse the needs of the consumer which physical planning should satisfy. This broadsheet, "Use and Misuse of Transport" (No. 211), reviewing first the general problems of pre-war transport in Great Britain, including the mounting delays, excessive journeys, travelling to work and the consequent loss of time, points out that if the full social costs are taken into consideration, the value of a great proportion of the transport which has been considered as normal is not com. mensurate with the price paid for it in money, time, energy, ill-health and loss of amenity. The position could not have been allowed to drift for many years longer without a real crisis developing. Dealing first with the comparatively limited question of reducing pressure on the roads, the broadsheet emphasizes that if travel by public vehicles in place of private car or vehicles is to be encouraged, accessibility is the key to the whole problem. More parking space and legal recognition of joint ownership of a car, the development of retail delivery services, and the utilization of any possibilities of underground travel as well as travel by air, are suggested; and the broadsheet gives a warning against allowing ourselves to be left behind in utilizing the air, as we were by the rapid development of the internal combustion engine.

The major possibilities, however, lie in the reduction of the demand for transport. The wider utilization of piped services and of the telephone in eliminating journeys is obvious, but the decentralization of services and amenities so as to rectify serious mistakes originally made in housing estates is also important. The major problem is that of reducing the journey to work, but there are limits to the alleviation which local employment can provide in this respect, and the broadsheet analyses closely the possibilities which zoning offers, particularly in regard to segregating traftic. Six different types of zone are enumerated, and discussing their interrelation, the broadsheet suggests that industry, warehouses and wholesale markets should be placed on the outskirts of a town; living quarters, offices, shops and schools would then be kept free from the intrusion of heavy traffic. Recent plans for large towns have shown a tendency in this direction. Such zoning, however, leads to the question whether synthesis is possible between the principles of the neighbourhood unit in which people's lives are localized, and of zoning, which is recommended for reasons of economic efticiency, of amenity and of a rational arrangement of transport. The problem of securing employment for people near their homes is more intricate than the decentralization of services and leisure facilities. While it is important that the light mobile industries should account for a much higher proportion of total employment, the issues cannot be decided purely from the point of view of transport, and a broad approach to this very broad problem is essential, as well as vision and boldness.

\section{Association of Scientific Workers of Southern Africa}

THE success achieved by the Association of Scientific Workers in Britain, the United States, and Australia, has inspired the establishment of a similar Association recently in South Africa, under the title of the Association of Scientific Workers of Southern Africa. Various problems such as the recent and still incomplete industrialization of the country, the widely scattered population, and the great distances between the few considerable urban and industrial centres, have necessitated an approach to problems of organization and policy differing a good deal from those adopted in Britain to achieve the same fundamental aims of promoting the application of science and the scientific method to the welfare of mankind, while at the same time furthering the professional interests of scientific workers. Also, the statutory position of a trade union is quite different in South Africa from that in Britain.

The establishment of the Association in South Africa met with a good response. The two branches, Johannesburg and Cape Town, now have a joint membership from all parts of the Union and the Rhodesias of more than 350. Public conferences have been arranged and have attracted considerable atten. tion. Memoranda have been presented to the Government Health Services Commission, and the Social and Economic Planning Council, and for publication, on various problems concerning the application of science to national problems. Recently the Association co-operated with the Medical Council in the matter of registration of laboratory technologists, who now form a large and enthusiastic group within the Association. The Association is also at work through special sub-committees, on war emergency' problems, education, research, finance and organization, and similar problems. It is expected that further branches will be established in the near future. The chairmen and addresses of the two existing branches are P. S. Malan, P.O. Box 1065, Cape Town, and Rena G. Knight, P.O. Box 8083, Johannesburg.

\section{Scientific Film Association}

THe Scientific Film Association was formally constituted at an extraordinary general meeting held on November 20. The primary aim of the new Association is to promote the national and international use of the scientific film in order to achieve the widest possible understanding and appreciation of scientific method and outlook, especially in relation to social progress. It will also collect, collate and distribute information on the scientific film, and publish comprehensive lists of films graded according to scientific merit and suitability for audiences. The Association hopes to establish relations with Government departments, public bodies and other organizations which are in a position to make, use or circulate scientific films ; and it is allso proposed to organize a representative panel of men of science to advise producers of films of all types on scientific matters in connexion with such films and to maintain close contact with 
the film industry. All inquiries should be made to M. Michaelis (honorary secretary), 51 Fitzjohn's Avenue, London, N.W.3.

\section{Prehistory in the Deccan}

So long ago as 1930, in the September number of Antiquity, Mr. M. C. Burkitt made an attempt to set out in some order the early archæological discoveries of south-east India. The bases for the study were the finds and notes made during a long period of years by Mr. L. A. Cammiade over a wide area of country including the districts along the lower reaches of the Godavari River. Actually, the finds made near this river were all from the surface and could not be accurately dated. They were, however, mostly microlithic in character; but it was clear that many ages were represented. Mr. H. D. Sankalia has now published a short article, "Studies in Prehistory of the Deccan (Maharashtra) : a Survey of the Godavari and the Kadva near Niphad" (Bull. Deccan Coll. Res. Inst., 4, No. 3) which, while not taking us much further, has a certain interest. Briefly, the Godavari has, in places, eut down through the trap to a low level, having previously deposited on the trap a series of gravels in which Mr. Sankalia has discovered a few artefacts in situ. Unfortunately, the illustrations are not very good, and it does not appear that any outstanding finds have been made, but $\mathrm{Mr}$. Sankalia is to be congratulated on having started an investigation which eventually may prove to be of considerable interest. It must always be remembered that the well-known micro-industries of the rock shelters in the Central Provinces of India, far from corresponding to the Mesolithic industries of Britain, are apparently for the most part postChristian in date. At the same time there are postMiddle Stone Age finds of small implements in the Cammiade collection which probably do date to Late Pleistocene times. Further work by Mr. Sankalia may help to elucidate these problems.

\section{St. John's Wort in Australia}

ST. JoHn's WORT (Hypericum perforatum var. angustifolium), introduced into Australia in about 1880 as a garden plant, is now a serious weed in many parts of that country. Besides reducing the carrying capacity of the pasture, stock may become affected with 'wort dermatitis', for the hypericin in the plant acts on the nervous system, rendering the exposed non-pigmented areas of their skin photosensitive. Control measures of various kinds are being tried, including improvement of the pasture by sowing competitive species, chemical treatment and the liberation of insect parasites. Some account of the success attending these trials is given in recent publications of the Australian Council for Scientific and Industrial Research. Bulletin 151 consists of a paper by R. M. Moore and A. B. Cashmore, who have investigated the problem from the agrostologist's point of view, while the entomological aspect is specially dealt with by F. Wilson and T. G. Campbell in the Council's Journal (16, p. 45). The results are most promising. Subterranean clover (Trifolium subterranean), a winter-growing annual, proved an efficient competitor with St. John's wort, and in association with perennial grasses, such as Phalaris tuberosa or Lolium perenne, almost completely eradicated the weed and provided a productive and nutritious pasture. The mixture is best sowr with a dressing of superphosphate after a summer fallow, a dense pasture being afterwards maintained by regular top-dressings and a rotational system of grazing. The use of dark-coloured stock is also recommended as they are less prone to wort dermatitis. For entomological control, three insects have been established in Australia, two leaf-eaters, Chrysolina hyperici and $C$.gemellata, and a root-boring Buprestid, Agrilus hyperici. The prospects of success are good, particularly with Agrilus, as it is remarkably free from predators and parasites, but the Chrysolina species have a high reproductive rate, and judging from experience in France, all three insects can play a useful part in the control of the weed.

\section{Stellar Spectrophotometry in the U.S.S.R.}

Two recent publications (Bull. Acad. Sci. Georgian S.S.R., 3, No. 6, p. 509 ; No. 7, p. 657; 1942) give news that astrophysics still flourishes just beyond the high-water mark of the German advance into southern Russia. At Abastumani Observatory an extensive programme of photo-electric colorimetry of $B 8-B 9$ stars was begun in the summer of 1940 and is still in progress. The colours of all stars of these spectral types brighter than 7.5 mag., lying in a zone within $20^{\circ}$ of the galactic equator, are being measured with an antimony-cæsium photo-cell attached to a $33 \mathrm{~cm}$. reflector. Colour filters give effective wavelengths of $4060 \mathrm{~A}$. and $5280 \mathrm{~A}$., the resulting colour equivalents being on a base-Iine slightly longer than ordinary photographically determined colour indexes. The greater sensitivity, range and stability of the antimony-cresium cell enables the Russian observers, V. Nikonov and E. Brodskaja, to obtain observations of which the probable error is less than \pm 0.01 mag. for stars brighter than the sixth magnitude, and less than $\pm 0.02 \mathrm{mag}$. for the fainter stars. When full results of this programme are available, they should add greatly to our knowledge of the selective absorption of light by interstellar matter situated fairly close to the sun.

Meanwhile, a vexed point regarding the colour temperature of $\alpha^{2}$ CVen is being investigated at Mt. Kanobili. Thirty-three observations of the star taken in the spring and summer of 1941 show a maximum variation of colour temperature of $2,000^{\circ}$, which agrees better with the spectrum changes than the value of $10,000^{\circ}$ found by Tai (Mon. Not. Roy. Astro. Soc., 100,$94 ; 1939)$. A puzzling feature of the observations is that the star is bluer at minimum than at maximum, a characteristic which differentiates it sharply from such intrinsic variables as Cepheids and long-period variables. Observations are being continued at Abastumani in happier circumstances than any obtaining since the inception of the programme.

\section{South African Institute for Medical Research}

THE annual report for 1942 of the South African Institute for Medical Research in Johannesburg indicates that this progressive Institute is playing its full part in the war effort. Staffed by 153 Europeans and 118 Africans, its activities are wide. In 1942, its buildings, which were no longer adequate to the large demands for serum for civilians and for army needs, were enlarged; a branch laboratory was established at Bloemfontein. The erection of a large plant for the manufacture of dried human and other serum was made possible by a grant of $£ 10,000$ from Sir Ernest Oppenheimer and the Anglo-American Corporation of South Africa. The production of 